\title{
Thrombotic Complications in Patients with COVID-19: Pathophysiological Mechanisms, Diagnosis, and Treatment
}

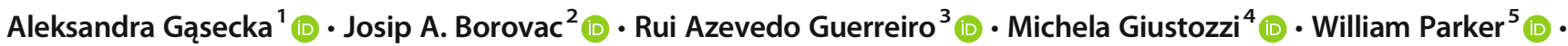 \\ Daniel Caldeira $^{6,7}$ (D) $\cdot$ Gemma Chiva-Blanch ${ }^{8,9}$ (1)
}

Accepted: 16 September 2020 / Published online: 19 October 2020

(C) The Author(s) 2020

\begin{abstract}
Introduction Emerging evidence points to an association between severe clinical presentation of COVID-19 and increased risk of thromboembolism. One-third of patients hospitalized due to severe COVID-19 develops macrovascular thrombotic complications, including venous thromboembolism, myocardial injury/infarction and stroke. Concurrently, the autopsy series indicate multiorgan damage pattern consistent with microvascular injury.

Prophylaxis, diagnosis and treatment COVID-19 associated coagulopathy has distinct features, including markedly elevated Ddimers concentration with nearly normal activated partial thromboplastin time, prothrombin time and platelet count. The diagnosis may be challenging due to overlapping features between pulmonary embolism and severe COVID-19 disease, such as dyspnoea, high concentration of D-dimers, right ventricle with dysfunction or enlargement, and acute respiratory distress syndrome. Both macro- and microvascular complications are associated with an increased risk of in-hospital mortality. Therefore, early recognition of coagulation abnormalities among hospitalized COVID-19 patients are critical measures to identify patients with poor prognosis, guide antithrombotic prophylaxis or treatment, and improve patients' clinical outcomes. Recommendations for clinicians Most of the guidelines and consensus documents published on behalf of professional societies focused on thrombosis and hemostasis advocate the use of anticoagulants in all patients hospitalized with COVID-19, as well as 2-6 weeks post hospital discharge in the absence of contraindications. However, since there is no guidance for deciding the intensity and duration of anticoagulation, the decision-making process should be made in individual-case basis.

Conclusions Here, we review the mechanistic relationships between inflammation and thrombosis, discuss the macrovascular and microvascular complications and summarize the prophylaxis, diagnosis and treatment of thromboembolism in patients affected by COVID-19.
\end{abstract}

Keywords COVID-19 $\cdot$ SARS-CoV-2 $\cdot$ Thrombosis $\cdot$ Inflammation $\cdot$ Venous thromboembolism $\cdot$ Prophylaxis

Aleksandra Gąsecka and Josip A. Borovac share joint first authorship - these authors contributed equally to this work.

\section{Key Features}

- There is a strong association between severe COVID-19 and thromboembolism.

- COVID-19-associated coagulopathy has distinct features.

- Symptoms of severe COVID-19 disease and pulmonary embolism overlap.

- Early recognition of thrombotic complications is critical to improve outcomes.

- Anticoagulation should be used in most patients hospitalized with COVID-19.

- There is no consensus regarding the anticoagulation intensity and duration.

Aleksandra Gąsecka

aleksandra.gasecka@wum.edu.pl

Extended author information available on the last page of the article

\section{Introduction}

The severe acute respiratory syndrome coronavirus 2 (SARSCoV-2), responsible for the coronavirus disease 2019 (COVID-19), originated in Wuhan, China, in December 2019. SARS-CoV-2 is a new ribonucleic acid (RNA) virus strain from the Coronaviridae family, firstly described by Zhou et al. in February 2020 [1]. In March 2020, COVID-19 was declared a pandemic by the World Health Organization (WHO), involving at the end of May more than 100 countries worldwide, number of cases and deaths rapidly increasing every day. On 25th June 2020, the WHO's 157th Situation Report of COVID-19 announced that more than 9 million people worldwide had been infected by this virus, which has caused almost 480,000 deaths in barely 6 months. Europe 
and America have been the most affected regions, accounting for almost $80 \%$ of worldwide cases and deaths [2]. Despite SARS-CoV-2 strains having a within-sequence identity of $99.98 \%$, it has been classified in 2 haplogroups (A and B), the first being the predominant worldwide and the second being more prevalent in America and Asia than in Africa and Europe [3]. Nevertheless, it remains unclear whether the severity and outcome of the disease are related to the virus strain.

SARS-CoV-2 fundamentally uses the angiotensinconverting enzyme 2 (ACE2) receptor to enter the cell through the binding with spike-like protein (S protein), although other cell receptors may be alternatively bound. In addition, ACE2 plays a major role in viral proliferation [4]. ACE2 is widely expressed in different organs and tissues, which concurs with the panoply of clinical systemic symptoms and multiorgan dysfunction presented with COVID-19, such as respiratory, renal, hepatic, gastrointestinal, and cardiac damage [5]. Both the down- and upregulation of ACE2 appear to play a major role in heart failure, hypertension, myocardial infarction, and overall cardiovascular disease (CVD) [6]. On those grounds, it is not surprising that patients with underlying CVD have 1.7fold higher mortality rate caused by COVID-19 than patients with chronic respiratory disease, despite the respiratory system being the principal target of the virus [7].

Emerging evidence points to a strong association between severe clinical presentation of COVID-19 and increased risk of thromboembolism, although the mechanisms behind this are not completely understood [8]. Several risk factors have been described for such an association, such as systemic hyperinflammation driven by the coronavirus infection, hypoxia, and comorbidities associated with hospitalization of critical patients [9]. Whence, understanding the clinical and mechanistic features of COVID-19 severity and mortality is critical to identify and treat patients at the highest thromboembolic risk and mortality. We aim to review the mechanistic relationships between inflammation and thrombosis, discuss the macrovascular and microvascular complications, and summarize the diagnosis, prophylaxis, and treatment of thromboembolism in patients affected by COVID-19.

\section{Mechanistic Relationships Between Inflammation and Thrombosis}

\section{Pathophysiology of Thrombosis}

The thrombotic response involves activation of platelets and the coagulation cascade [10]. Remembering Virchow's triad, changes in the blood flow, constituents, or vessel wall can precipitate thrombosis [11]. Platelet activation is initiated by several agonists, including collagen via glycoprotein (GP) VI receptors and thrombin via protease-activated receptors (PAR) 1 and 4. Upon activation, several key processes occur.
First, arachidonic acid is converted to thromboxane $\mathrm{A}_{2}$, a potent pro-aggregatory and vasoconstrictive factor [12]. Second, platelets degranulate. Dense granules, containing adenosine diphosphate (ADP), fuse with the cell membrane [13]. ADP then acts on platelet $\mathrm{P} 2 \mathrm{Y}_{1}$ and, most importantly, $\mathrm{P}_{2} \mathrm{Y}_{12}$ receptors, further stimulating and amplifying platelet activation [14]. Similarly, alpha granules, containing P-selectin as well as other proinflammatory and procoagulant factors, fuse with the membrane. P-selectin binds to a range on inflammatory cells, including neutrophils and monocytes [15]. Thirdly, through calcium mobilization and dephosphorylation of vasodilator-stimulated phosphoprotein (VASP), platelets undergo shape change from discoid to stellate forms, meaning physical aggregation occurs [16]. Conformational change in the GP IIb/IIIa receptor, which forms cross-links with other GP IIb/IIIa, strengthening platelet-platelet binding, and also stimulating other platelets to activate via outside-in signalling [17]. In addition, platelets and vascular and blood cell also release extracellular vesicles by outward blebbing, which are small particles released by almost all cell types when activated or injured, and composed by multiple bioactive molecules such as RNA, miRNA, cytokines, transcription and growth factors, and even small amounts of DNA, and lipids (they are rich in phospholipids) because they are enveloped in a lipid bilayer cell-derived membrane [18, 19]. Some extracellular vesicles expose phosphatidylserine in their external layer and therefore elicit a 50- to 100 -fold higher procoagulant activity than activated platelets [20].

In addition to platelets and extracellular vesicles, activation of the coagulation cascade plays an important role in thrombosis [21]. Broadly divided into two converging pathways, activation of the extrinsic pathway by tissue factor and/or contact activation of the intrinsic pathway, coagulation cascade leads to activation of factor $\mathrm{X}$, a constituent of the prothrombinase complex, resulting in thrombin generation. Thrombin cleaves soluble fibrinogen to insoluble fibrin, which forms interweaving strands, further stabilized by factor XIII. There is interplay between the coagulation cascade and platelets. Not only can thrombin activate platelets through PAR1 and PAR4, but also conversely platelets themselves can catalyze thrombin generation via membrane scramblase activity [22].

Although there is considerable overlap between plateletand coagulation-mediated effects, the prominent mechanism of initiation varies by setting. Platelet activation is typically most prominent, whereas, [23] whereas in the venous circulation activation of the coagulation cascade predominates [24].

\section{The Inflammatory Response}

The inflammatory response includes a complex network of factors, triggered by insults such as infection, trauma, or 
toxicity. Broadly, this is initiated by damage pattern recognition receptors found on a range of leukocytes [25]. This leads to recruitment and translocation of other leukocytes, release of cytokines and other inflammatory mediators, activation of complement, and physical attack of pathogens or infected cells [26]. Specifically in COVID-19-associated systemic inflammation, severe disease is associated with increased levels of cytokines such as interleukin (IL)-6, tumor necrosis factor (TNF)- $\alpha$, and IL-2R [27]. Levels of, for example, IL-6 have also been associated with outcomes in severe COVID-19 [28].

\section{Role of Platelets During Inflammation}

Platelets too play an important role in the regulation and enactment of the inflammatory response. Acute inflammation, for example, during endotoxemia, is associated with increased number of platelet-monocyte and platelet-neutrophil aggregates, mediated via enhanced P-selectin expression. Inhibiting platelets with $\mathrm{P} 2 \mathrm{Y}_{12}$ inhibitors in this setting leads to in lower detectable plasma levels of cytokines such as IL-6 and TNF- $\alpha[29,30]$.

Platelet reactivity, measured by numerous assays, is increased during acute inflammatory states, for example, sepsis [31]. Platelets themselves are acute phase reactants and inflammation induces thrombocytosis, mediated by an increase in thrombopoetin levels, potentiated by interleukin-6 [32]. Moreover, markers correlating closely with thrombotic risk, such as mean platelet volume and immature platelet fraction, or increased levels of circulating extracellular vesicles derived from platelets and leukocytes are increased during acute inflammation [33-35]. Raised circulating levels during inflammation of other platelet agonists such as adrenaline, via $\alpha_{2}$ receptors and serotonin (5-HT), via $5-\mathrm{HT}_{2 \mathrm{~A}}$ receptors, may also contribute to enhanced reactivity $[36,37]$.

\section{Role of Acellular Coagulation During Inflammation}

Acute inflammation, triggered by a virus infection, for instance, is also associated with prothrombotic changes in fibrin clot dynamics, including increased fibrin strand density and clot turbidity [29]. Similarly, levels of markers such as Ddimer and fibrinogen may be elevated. Thrombin generation, which is increased during inflammation [38], drives not only coagulation and platelet activation but also inflammation more directly through promotion of leukocyte recruitment [39]. Conversely, severe inflammation can lead to such an increase in prothrombotic tendency that widespread microvascular thrombosis occurs, known as disseminated intravascular coagulation. This results in a fall in detectable clotting factors as these are consumed rapidly, and can paradoxically lead to reduced hemostatic function and therefore increased bleeding risk [40].

\section{Effect of Inflammation on the Endothelium}

Endothelial function is adversely affected during systemic inflammation. In particular, the release of von Willebrand factor (vWF) is increased, which facilitates platelet-endothelium and platelet-platelet binding, On the contrary in the activity of the antithrombotic factors tissue factor pathway inhibitor and protein $\mathrm{C}$ are reduced[41]. In the arterial circulation, inflammation can also drive atheromatous plaque progression, impacting on local hemodynamics and also on plaque stability, making plaque rupture or erosion events, which can trigger thrombosis, more likely [42].

\section{Macrovascular Complications}

One-third of patients hospitalized due to severe COVID-19 develop macrovascular thrombotic complications which are associated with an increased risk of in-hospital mortality [43, 44]. These complications include especially venous thromboembolism (VTE), and also stroke and acute myocardial infarction.

\section{Venous Thromboembolism}

Elevated D-dimer concentration and thrombotic microangiopathy in pulmonary vessels on autopsy have raised the concern of pulmonary embolism (PE) as a reason of acute respiratory failure in patients with COVID-19. The in-hospital incidence of acute PE differs among studies, with the highest rate in severely ill patients admitted to intensive care unit (ICU) [45-56]. In a case series of 12 patients with severe COVID19 , post-mortem autopsies showed that VTE occurred in 7 of $12(58 \%)$ patients, with PE being the direct cause of death in 4 of them (33\%) [57]. To date, the largest published study included 388 patients [45]. Of these, $16 \%$ patients were admitted to the ICU. The cumulative rate of thromboembolic event was $21 \%$, rising from $7 \%$ of patients admitted to the general ward to $28 \%$ of patients in the ICU. By pooling the data of all the studies (1765 patients) reporting the frequency of VTE in COVID-19, the overall incidence of VTE was 21.9\% [8]. This cumulative incidence ranged from $31.3 \%$ in studies that included more than $75 \%$ ICU patients to $8.6 \%$ in studies that included less than $75 \%$ ICU patients. The high heterogeneity observed between the studies reflects the discrepancies of the inclusion criteria (e.g., patients with PE only vs. patients with PE with/without deep vein thrombosis [DVT]), thromboprophylaxis strategies, and definition of outcomes. This heterogeneity may lead to bias, highlighting the urgent need for further high-quality prospective research.

Only a few studies have reported the anatomical location of acute PE in COVID-19 patients [45, 47, 49, 58]. In a retrospective study of 137 patients with COVID-19, in which all 
patients underwent computed tomography pulmonary arteriography (CTPA) of the pulmonary arteries, a total of $32 \mathrm{PE}$ were identified, of which ten were proximal PE, 18 involved segmental pulmonary arteries, and the remaining four PE were multiple subsegmental pulmonary arteries [58]. The segmental and subsegmental location of PE was also the most common in other studies $[45,49,53]$. It should be noted that only about one-third of COVID-19 patients undergo CTA during the hospital stay $[45,49,53]$. The risk of infection for both operators and other patients and the difficulties in performing CTPA in mechanical ventilated patients in prone position are the main reasons for the relatively low frequency of CTPA in these patients. Consequently, it cannot be excluded that the incidence of acute PE has been underestimated in patients with COVID-19.

Current data on the incidence of DVT in patients with COVID-19 are rather poor. In a recent study of 143 patients with COVID-19 undergoing ultrasonography of the lower limbs, DVT was found in $46.1 \%$ of patients [59]. Of these, $23(34.8 \%)$ were proximal and 43 (65.2\%) were distal DVTs. The Padua prediction score of 4 or higher and a D-dimer greater than $1.0 \mu \mathrm{g} / \mathrm{ml}$ were significantly associated with a more than 4-fold increased risk of DVT. Noteworthy, among distal vein thrombosis, $65 \%$ was in the intramuscular veins, regardless of whether it was symptomatic or asymptomatic. The clinical and prognostic meaning of asymptomatic distal DVT in these patients remains to be determined.

\section{Arterial Thrombosis}

Both stroke and acute myocardial infarction have been described in patients with COVID-19. In observational studies, the proportion of COVID-19 patients with stroke ranges from 2.7 to $3.8 \%$ [45, 47, 48, 50, 53]. By pooling the available data (973 patients), the overall prevalence of in-hospital acute stroke is $3.5 \%$ (95\% CI $2.4-4.8 \%$ ), without statistical heterogeneity between the studies [8]. Both ischemic and hemorrhagic stroke can complicate the course of COVID-19. In a series of 6 patients, 4 patients had an ischemic stroke and 2 patients a hemorrhagic stroke [60]. Acute stroke in patients with COVID-19 is often associated with pre-existing cardiovascular risk factors and is a negative prognostic factor [61]. The mechanisms by which SARS-CoV-2 infection can trigger stroke depend on the associated pathogen and host characteristics. The presence of a prothrombotic state or a vasculitislike mechanism may partly explain this association [60].

Myocardial injury indicated by increased troponin level may occur in $7-17 \%$ of COVID-19 patients admitted to the general ward and in $22-31 \%$ of those admitted to the ICU [ 44 , $62,63]$. In a recent meta-analysis of 8 studies from China including 46,248 infected patients, $7 \%$ of patients experienced myocardial injury ( $22 \%$ of the critically ill), as evidenced by elevated cardiac troponin [64]. Noteworthy, patients with myocardial injury had higher in-hospital mortality (37.5\%) than patients with cardiovascular disease (CVD) but without myocardial injury (13.3\%), or patients without CVD (7.6\%). Moreover, if myocardial injury was present in patients with pre-existing CVD, the mortality increased even more (69.4\%) [65]. It was also demonstrated that myocardial injury is an equivalent to previous myocardial infarction in terms of mortality risk in COVID-19 patients [43]. Clearly, myocardial injury and underlying CVD markedly deteriorate the prognosis in COVID-19. The possible mechanisms explaining this association include (i) cytokine storm, (ii) microangiopathy, (iii) viral myocarditis, (iv) stress-induced cardiomyopathy, and (iv) classic myocardial infarction due to infectioninduced atherosclerotic plaque instability [66, 67].

The management of both acute ischemic stroke and acute myocardial infarction can be challenging in these patients due to the need of urgent reperfusion and frequent lack of standard procedures to perform reperfusion in COVID-19 patients, essential to ensure the best care of patients. The role of venoarterial extracorporeal membrane oxygenation (ECMO) as a form of rescue therapy in the case of COVID-19-associated cardiovascular collapse is currently under investigation.

\section{Microvascular Complications}

Microvascular thrombosis is defined as pathological occlusion of microvessels (arterioles, capillaries, and venules) by platelet- and/or fibrin-rich thrombi [68]. Classically, microvascular thrombosis includes thrombotic microangiopathies (e.g., thrombocytic thrombocytopenic purpura, hemolyticuremic syndrome) and disseminated intravascular coagulation (DIC) [69]. Microvascular thrombosis is a diagnostic challenge, because (i) microthrombi are difficult to visualize due to their small size (often $\leq 10 \mu \mathrm{m}$ ), (ii) microthrombi often occur only transiently, and (iii) specific biomarkers to detect them are lacking [68]. Clinically, microvessel occlusion leads to ischemia, with the effects ranging from alterations in plasma coagulation markers to severe multiorgan failure [70]. Although in most cases the evidence indicating a causal relationship between microvascular thrombosis and organ failure is difficult to obtain, microvascular thrombosis appears to have a critical importance in the course of COVID-19 [71].

Emerging evidence shows that severe COVID-19 can be complicated with coagulopathy of a prothrombotic character and is associated with poor prognosis [72]. Although many patients with severe COVID-19 present with coagulation abnormalities that mimic thrombotic microangiopathy or DIC, COVID-19-associated coagulopathy has distinct features [73]. The first autopsy series of four patients who died due to severe COVID-19 demonstrated a unique pathological picture, with the presence of diffuse microthrombosis and hemorrhage along with abundant intravascular megakaryocytes in 
all major organs, including the lungs, heart, kidneys, and liver [74]. Since the gross pulmonary thromboembolism and parenchymal inflammation were absent, this picture has been described as pauci-inflammatory thrombogenic vasculopathy. Another autopsy series of five patients with COVID-19 and acute respiratory distress syndrome (ARDS) demonstrated the lung and skin damage consistent with complement-mediated microvascular injury, whereas the hallmarks of classic ARDS with diffuse alveolar damage and hyaline membranes were not prominent [75]. The distinct respiratory distress syndrome accompanying severe COVID-19 has been termed microvascular COVID-19 lung vessels obstructive thromboinflammatory syndrome (MicroCLOTS) [76] or lung-restricted vascular immunopathology [77].

The pathophysiological mechanisms underlying COVID19-associated coagulopathy are summarized in Fig. 1. These mechanisms seem to follow Virchow's triad, including (i) diffuse endothelial cell injury, (ii) abnormal blood flow dynamics, and (iii) uncontrolled platelet activation [71]. SARSCoV-2 enters the target cells through the ACE2 receptors, which are widely expressed on the surface of lung epithelial cells, and arterial and venous endothelial cells in multiple organs [78]. Virus infection causes direct endothelial injury, dysfunction, and prothrombotic gene expression [79]. In addition to the direct effect, the virus triggers innate immune responses, including the activation of monocytes and complement cascade, responsible for a massive local release of proinflammatory cytokines and aggravation of endothelial injury and microvascular thrombosis, termed immunothrombosis [76]. The major mediators of immunothrombosis include tissue factor (TF) and neutrophils. $\mathrm{TF}$, exposed particularly by activated monocytes and monocyte-derived extracellular vesicles, is a major initiator of thrombosis in vivo [80]. Neutrophils, in turn, stabilize microthrombi via the release of neutrophil extracellular traps (NETs) and neutrophil elastase, which immobilize inflammatory cells and promote intravascular fibrin formation via degradation of TF antagonist, a tissue factor pathway inhibitor [81].

Abnormal flow dynamics results from high blood concentrations of vWF, cell-free DNA, histones, and viral RNA in course of COVID-19, which all cause factor XI activation, thrombin generation, and intravascular fibrin formation, leading to change in blood flow rheology [82]. Platelet activation is induced both indirectly by NETs and directly by virus infection. NETs lead to platelet activation via toll-like receptors on platelets and other cells, therefore integrating pulmonary infection, inflammation, and thrombosis [83, 84]. There is data showing that platelets and megakaryocytes may have receptors for viruses [85-87] and could be infected by earlier SARS-CoV [88]. Although currently there is no evidence of direct infection of platelets or megakaryocytes by SARS-
Fig. 1 The pathophysiological mechanisms underlying COVID19-associated coagulopathy. These mechanisms seem to follow Virchow's triad, including (i) diffuse endothelial cell injury, (ii) abnormal blood flow dynamics, and (iii) uncontrolled platelet activation [71]

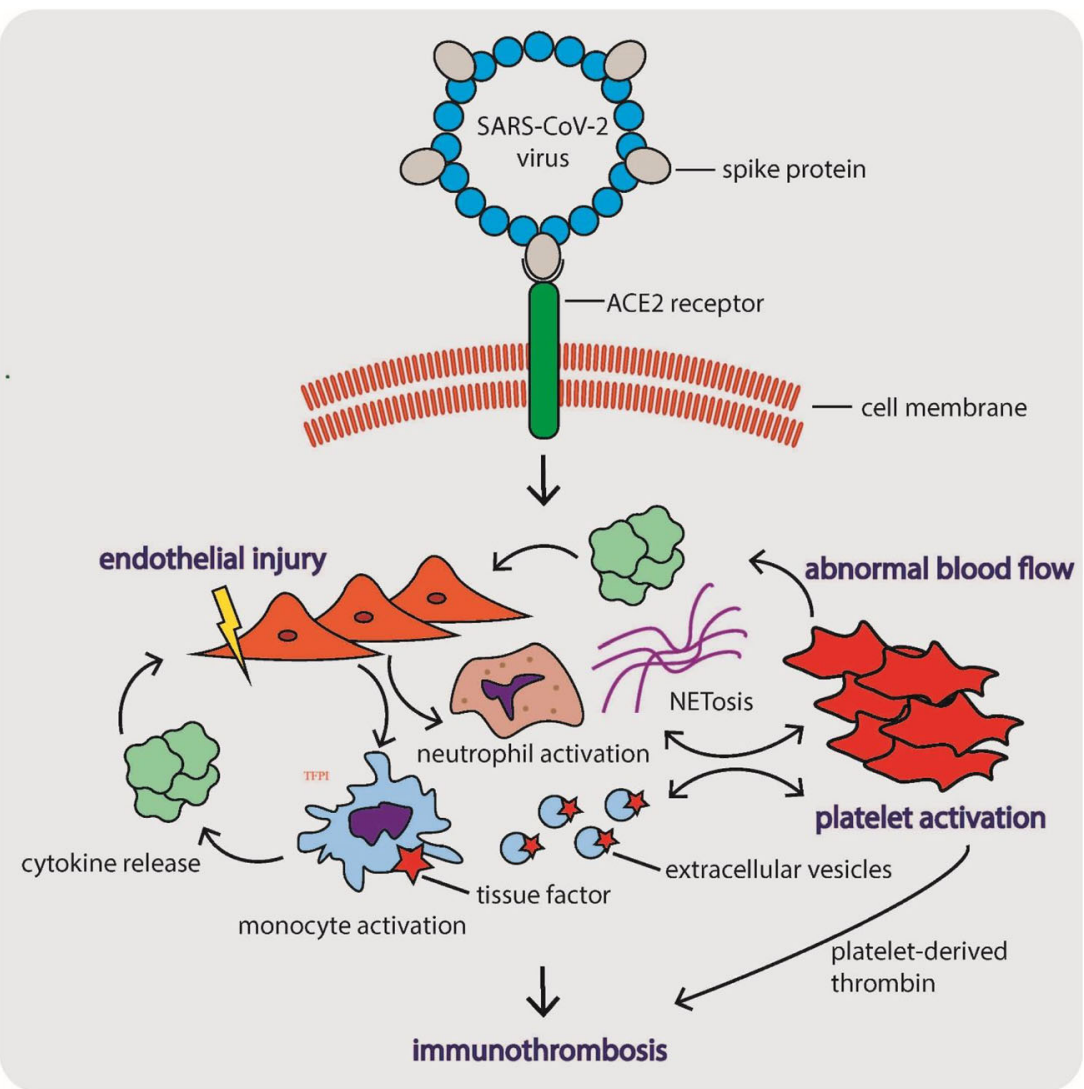


CoV-2, the abundance of megakaryocytes in the lungs at autopsy seems to co-localize with platelet-rich thrombi [7]. Altogether, the immunothrombosis pathway in the lungs might be a starting point for the systemic propagation of COVID-19 infection, but more research is needed to elucidate this process.

Altogether, the mechanisms underlying microvascular thrombosis in course of COVID-19 may be related to diffuse vascular endothelial cell injury, hyperimmune reaction of the host, and maladaptive platelet aggregation. Clinician awareness of microvascular thrombosis during COVID-19 infection is crucial, since prompt recognition may be life-saving [89].

\section{Diagnosis, Prophylaxis, and Treatment of Thromboembolism}

Thrombosis and thromboembolic complications in patients hospitalized with COVID-19 should be assessed by integrating physical examination findings, patient history, results of laboratory tests reflecting hemostasis, and/or results of focused imaging investigations. Patients who exhibit signs and symptoms of DVT and have risk factors for thrombosis (previous thrombotic events, active malignancy, or current use of hormonal therapy), unexplained and sudden deterioration in respiratory status, and unexplained hypotension and/or tachycardia should be further clinically evaluated to rule out thrombotic complications. In patients with high suspicion of thrombosis, most readily available imaging studies such as bilateral compression ultrasonography of the legs and/or bedside pointof-care cardiac ultrasonography should be used to detect proximal DVT, myocardial thrombus, clot-in-transit to the pulmonary trunk or right ventricular dilatation [92-95]. However, negative findings of these tests are insufficient to fully exclude thrombosis [92-95]. If the underlying etiology of persisting hemodynamic and respiratory compromise is not detected by less complex imaging modalities, a CTPA should be undertaken. On the other hand, a normal D-dimer test performed with high-sensitivity assays in this population reasonably rules out VTE, while positive D-dimer test does not confirm thrombosis, and therefore, a further imaging workup is warranted. Table 1

Importantly, elevations of laboratory parameters indicating hypercoagulability at the admission of patients with COVID19 are associated with an increased incidence of in-hospital thromboembolic events and mortality [44, 52, 72, 96-98]. For example, in a recent report including 2377 consecutive adults hospitalized with COVID-19, $76 \%$ of patients had elevated Ddimer at presentation which had prognostic value for the severe course of COVID-19 infection, including 2-fold higher odds for critical illness, thrombotic events, acute kidney injury, and death. Importantly, the rates of adverse events increased with the magnitude of D-dimer elevation [99]. The initial prothrombotic cascade in patients with COVID-19 is similar as in critical patients with DIC and consumptive coagulopathy; however, there are clear differences between COVID-19-associated coagulopathy and patients that have classical DIC. Notably, coagulopathy in COVID-19 patients is primarily characterized by the marked elevations in Ddimer and fibrin/fibrinogen degradation product levels while thrombocytopenia and prolongations of activated partial thromboplastin time (aPTT) and/or prothrombin time (PT) are less common or usually mild [100]. Accordingly, a hyperfibrinolytic consumptive DIC with a bleeding diathesis is a rare and unlikely event in these patients [100]. A worsening trend of coagulation parameters during an ICU stay generally indicates impending clinical deterioration, development of cytokine storm, and progression to multiorgan failure [101]. The procoagulant pattern in severe COVID-19 patients, assessed by standard laboratory and viscoelastic tests, revealed increased clot strength (CS), increased platelet and fibrinogen contribution to CS, elevated D-dimer levels, and hyperfibrinogenemia [102]. Similarly, a complete lack of fibrinolysis of a clot at $30 \mathrm{~min}$ and exuberant increase in Ddimer levels were strongly associated with thromboembolic events and renal failure [97]. Furthermore, levels of C-reactive protein (CRP), IL-6, factor VIII, vWF, and plasma viscosity are increased in these patients while antithrombin is modestly decreased thus clearly showing a cross-link between infection-induced inflammatory response and thrombosis, known as infection-induced thromboinflammation [100, 102-104]. A summary of the most important laboratory parameters reflecting hemostasis derangement in patients with COVID-19 is shown in Table 2.

In terms of laboratory workup, measurements of D-dimer levels, PT/aPTT, thrombocyte count, and fibrinogen levels (if assays are available) are advised to identify hospitalized COVID-19 patients at a high risk of poor in-hospital outcomes, or to triage patients that would require hospital admission and close monitoring $[105,106]$. Repeated assessments (every 2-3 days) of D-dimer, PT, and the platelet count at the minimum should be integrated into the diagnostic approach, as recommended by the documents of relevant societies [73, 106]. PT expressed as an international normalized ratio (INR) should not be used to monitor hemostasis in COVID-19 patients, since it mostly lies in the normal range. Early recognition and vigilant monitoring of coagulation abnormalities among hospitalized COVID-19 patients are critical measures to (i) identify patients at a high risk of poor prognosis, (ii) guide antithrombotic prophylaxis or treatment to prevent thromboembolic complications, and (iii) improve patients' clinical outcomes.

Most of the guidelines and consensus documents published on behalf of professional societies focused on thrombosis and hemostasis advocate the use of prophylactic doses of anticoagulants in all patients hospitalized with COVID-19 in the 
Table 1 The summary of studies reporting the frequency of VTE complications in COVID-19 patients

\begin{tabular}{|c|c|c|c|c|c|c|c|c|c|}
\hline Studies & Study design & $\begin{array}{l}\text { No. } \\
\text { of pts }\end{array}$ & Setting & Male & $\begin{array}{l}\text { Mean } \\
\text { age }\end{array}$ & $\begin{array}{l}\text { Median } \\
\text { follow- } \\
\text { up }\end{array}$ & $\begin{array}{l}\text { Rates of } \\
\text { PE during } \\
\text { follow-up }\end{array}$ & $\begin{array}{l}\text { Incidence } \\
\text { of VTE }\end{array}$ & Use of thrombophophylaxis \\
\hline Lodigiani et al. [45] & $\begin{array}{l}\mathrm{R} \\
\text { Single center }\end{array}$ & 388 & $\begin{array}{l}\text { ICU and } \\
\text { general } \\
\text { ward }\end{array}$ & $58 \%$ & 66 & 10 days & $4.4 \%$ & $21 \%$ & $\begin{array}{l}\text { Enoxaparin or nadroparin. } \\
\text { ICU, } 100 \% \text {; Ward, } 75 \% \text {. } \\
\text { Regimen not specified }\end{array}$ \\
\hline Poissy et al. [46] & $\begin{array}{l}\mathrm{R} \\
\text { Single center }\end{array}$ & 107 & ICU & $59.1 \%$ & 57 & 6 days & $20.6 \%$ & $20.4 \%$ & $\begin{array}{l}20 \text { out of the } 22 \text { PE patients } \\
\text { were on prophylactic } \\
\text { LMWH or UFH, but } \\
\text { exact agents not specified. }\end{array}$ \\
\hline Klok et al. $[47,48]$ & $\begin{array}{l}\mathrm{R} \\
\text { Multicenter }\end{array}$ & 184 & ICU & $76 \%$ & 64 & 10 days & $37 \%$ & $57 \%$ & Varied by center. \\
\hline Middeldorp et al. [49] & $\begin{array}{l}\mathrm{R} \\
\text { Single center }\end{array}$ & 198 & $\begin{array}{l}\text { ICU and } \\
\text { general } \\
\text { ward }\end{array}$ & $66 \%$ & 61 & 5 days & $17 \%$ & $\begin{array}{l}15 \% \text { at } 7 \\
\text { days } \\
34 \% \text { at } 14 \\
\text { days }\end{array}$ & $\begin{array}{l}\text { ICU: nadroparin } 2850 \mathrm{IU} \\
\text { BID if weight }<100 \mathrm{~kg}, \\
\text { and } 5700 \mathrm{IU} \text { BID if } \\
\text { weight }>100 \mathrm{~kg} \text {. Ward } \\
\text { patients had half this dose }\end{array}$ \\
\hline Helms et al. [50] & $\begin{array}{l}\mathrm{R} \\
\text { Multicenter }\end{array}$ & 150 & ICU & $81 \%$ & 63 & NR & $18 \%$ & NR & $\begin{array}{l}\text { LMWH (exact agent not } \\
\text { specified) } 4000 \text { Units per } \\
\text { day or UFH 5-8 U/kg/h }\end{array}$ \\
\hline Llitjos et al. [51] & $\begin{array}{l}\mathrm{R} \\
\text { Double } \\
\quad \text { center }\end{array}$ & 26 & ICU & $77 \%$ & 68 & NR & $23 \%$ & NR & $\begin{array}{l}\text { LMWH and UFH were used } \\
\text { (exact agents not specified) }\end{array}$ \\
\hline Thomas et al. [53] & $\begin{array}{l}\mathrm{R} \\
\text { Single center }\end{array}$ & 63 & $\begin{array}{l}\text { ICU and } \\
\text { general } \\
\text { ward }\end{array}$ & $69 \%$ & 59 & 8 days & $9 \%$ & $27 \%$ & $\begin{array}{l}\text { All patients assessed for use } \\
\text { of prophylaxis with } \\
\text { weight-adjusted dalteparin }\end{array}$ \\
\hline $\begin{array}{l}\text { Leonard-Lorant et al. } \\
\text { [54] }\end{array}$ & $\begin{array}{l}\mathrm{R} \\
\text { Double } \\
\quad \text { center }\end{array}$ & 106 & $\begin{array}{l}\text { ICU and } \\
\text { general } \\
\text { ward }\end{array}$ & $66 \%$ & 63.5 & NR & $30 \%$ & NR & $\begin{array}{l}\text { Anticoagulant not specified. } \\
\text { In PE + group, } 78 \% \text { were } \\
\text { on prophylactic doses and } \\
6 \% \text { were on therapeutic } \\
\text { doses. }\end{array}$ \\
\hline Grillet et al. [55] & $\begin{array}{l}\mathrm{R} \\
\text { Single center }\end{array}$ & 100 & $\begin{array}{l}\text { ICU and } \\
\text { general } \\
\text { ward }\end{array}$ & $70 \%$ & 66 & NR & $23 \%$ & NR & NR \\
\hline Bompard et al. [58] & $\begin{array}{l}\mathrm{R} \\
\text { Double } \\
\quad \text { center }\end{array}$ & 135 & $\begin{array}{l}\text { ICU and } \\
\text { general } \\
\text { ward }\end{array}$ & $70 \%$ & 64 & 5 days & $23.7 \%$ & $\begin{array}{l}50 \% \mathrm{ICU} \\
18 \% \mathrm{GW}\end{array}$ & $\begin{array}{l}\text { All patients received standard } \\
\text { dose of prophylaxis (Enox } \\
4000 \text { daily in GW, twice } \\
\text { daily in obese and ICU } \\
\text { patients) }\end{array}$ \\
\hline $\begin{array}{l}\text { Galeano-Valle et al. } \\
\text { [90] }\end{array}$ & $\begin{array}{l}\mathrm{P} \\
\text { Single center }\end{array}$ & 24 & $\begin{array}{r}\text { General } \\
\text { ward }\end{array}$ & $58 \%$ & 64.3 & 14 days & $6.5 \%$ & NR & $\begin{array}{l}\text { All patients received } \\
\text { standard dose of } \\
\text { prophylaxis (enoxaparin } \\
4000 \text { UI daily or } \\
\text { bemiparin } 3500 \text { UI daily) }\end{array}$ \\
\hline Hippensteel et al. [91] & $\begin{array}{l}\mathrm{R} \\
\text { Single center }\end{array}$ & 91 & ICU & $58 \%$ & 55 & NR & $5.5 \%$ & $26.1 \%$ & $\begin{array}{l}54.3 \% \text { of patients received } \\
\text { therapeutic anticoagulation }\end{array}$ \\
\hline
\end{tabular}

$P$, prospective; $R$, retrospective; $I C U$, intensive care unit; $N R$, not reported; $L M W H$, low molecular weight heparin; $U F H$, unfractionated heparin

absence of contraindications [105-108]. Likewise, extendedduration thromboprophylaxis with low molecular weight heparin (LMWH) or a non-vitamin $\mathrm{K}$ antagonist oral anticoagulants (NOAC) for 2 to 6 weeks post-hospital discharge might be applied to hospitalized COVID-19 patients, especially those with no bleeding risk factors and with high VTE risk post-discharge (most commonly defined as advanced age, long stay in the ICU, malignancy, prior VTE history, thrombophilia, severe immobility, D-dimer levels $>2$ times of upper reference range, an IMPROVE VTE score $\geq 4$, and similar). Such recommendations are made due to observed hypercoagulability and a robust number of studies that consistently showed a high incidence of thromboembolic complications, especially venous thromboembolism in hospitalized and particularly ICU-treated COVID-19 patients [45, 46, 48, 49, 52]. Likewise, most of the available documents support the possibility to initiate intermediate-dose LMWH in selected severe COVID-19 patients by individually balancing 
Table 2 Laboratory tests reflecting hemostasis in patients with COVID-19 associated coagulopathy

\begin{tabular}{|c|c|c|}
\hline \multicolumn{2}{|l|}{ Laboratory variable } & COMMENTS \\
\hline \multicolumn{3}{|c|}{ Standard coagulation and platelet panel } \\
\hline D-dimer & $\uparrow \uparrow \uparrow$ & $\begin{array}{l}\text { Markedly elevated } \\
\text { 3- to 4-fold elevation associated with high mortality }\end{array}$ \\
\hline FDPs & $\uparrow \uparrow$ & Elevated \\
\hline Fibrinogen & $\begin{array}{l}\uparrow \uparrow \\
(\downarrow)\end{array}$ & $\begin{array}{l}\text { Elevated } \\
\text { Decreasing trend if patient's condition progresses towards } \\
\text { consumptive coagulopathy phenotype (e.g., DIC) }\end{array}$ \\
\hline aPTT & $\longleftrightarrow(\uparrow)$ & In normal range OR slightly prolonged \\
\hline PT & $\longleftrightarrow(\uparrow)$ & In normal range OR slightly prolonged \\
\hline Platelet count & $\longleftrightarrow(\downarrow)(\uparrow)$ & $\begin{array}{l}\text { Near normal OR mildly decreased } \\
\text { Ranging from } 100-150 \times 10^{9} \text { cells } / \mathrm{L} \text { in } 70-95 \% \text { patients with } \\
\text { severe COVID- } 19 \text {, platelet count }<100 \times 10^{9} \text { cell } / \mathrm{L} \text { was detected } \\
\text { in about } 5 \% \text { of severe COVID- } 19 \text { patients. Could be slightly } \\
\text { increased based on limited data from small cohorts }\end{array}$ \\
\hline \multicolumn{3}{|c|}{ Advanced rheological parameters } \\
\hline Plasma viscosity & $\uparrow \uparrow$ & Increased 2-fold, on average \\
\hline Factor VIII activity & $\uparrow$ & Increased \\
\hline von Willebrand factor & $\uparrow$ & Increased \\
\hline Antithrombin activitiy & $(\downarrow)$ & Modestly decreased \\
\hline Free protein $\mathrm{S}$ & $(\downarrow)$ & Modestly decreased \\
\hline Protein C & $(\uparrow)$ & Modestly increased \\
\hline
\end{tabular}

$a P T T$, activated partial thromboplastin time; FDPs, fibrin degradation products; $P T$, prothrombin time. $\longleftarrow$ indicates normal range. $(\uparrow)$ and $(\downarrow)$ denote modest increase or decrease, respectively; $\uparrow$ and $\downarrow$, slightly increase or decrease, respectively; $\downarrow \downarrow$ and $\downarrow \downarrow$, considerably increase or decrease, respectively; and $\uparrow \uparrow \uparrow$ and $\downarrow \downarrow \downarrow$ strongly increase or decrease, respectively thrombotic and bleeding risk. Finally, in hospitalized COVID19 patients with verified VTE, the aforementioned consensus statements stimulate the use of full therapeutic doses of antithrombotic drugs (LWMH as most preferred, followed by unfractionated heparin) in all patients without contraindications, with carefully monitoring renal function, thrombocyte count, and concomitant medications. Antithrombotic prophylactic and therapeutic regimens in various clinical scenarios as recommended by relevant societies are shown in Table 3.

A treatment rationale for recommendations elaborated above is also partially based on the reported survival benefits, if the anticoagulation regimen is initiated in these patients. Of note, one study showed that treatment with prophylactic doses of LMWH was associated with lower 28-day mortality among patients with severe COVID-19 that had sepsis-induced coagulopathy score $\geq 4$ or D-dimers $>6$-fold of an upper limit of normal, compared with LMWH non-users [109]. However, the crude difference between the unselected group of patients that received LMWH vs. non-receivers in 28-day mortality endpoint was not significantly different. Similarly, another study found the significantly increased probability of survival in 2773 hospitalized COVID-19 patients if systemic anticoagulation was initiated, compared with if it was not, especially among patients that required mechanical ventilation [110]. One of the putative explanations for the beneficial effect of heparin and its derivatives in COVID-19 is based on the fact that heparins exhibit pleiotropic actions beyond anticoagulation, including direct anti-inflammatory action, as demonstrated by the decreased levels of inflammatory biomarkers in pre-clinical and clinical settings [111, 112]. Given that the severe inflammatory response in COVID-19 is the principal driver of coagulopathy, the concept of using heparin and its derivatives seems clinically validated as they likely blunt both thrombotic and inflammation pathways, thus improving outcomes in these patients.

\section{Recommendations for Clinicians}

COVID-19 caused by SARS-CoV-2, at the severest stages might be considered as a thromboinflammatory disease rather than an infection. In fact, the presence of microthrombotic pulmonary disease led to the suspicion that pulmonary macro- or microembolism could play a role in the pathophysiology and clinical deterioration of COVID-19 patients [1, 113]. The diagnosis of PE or MicroCLOTS may be challenging, because there are some overlapping features between pulmonary embolism and severe COVID-19 disease, such as dyspnoea, high levels of D-dimers, right ventricle with systolic dysfunction or enlargement, and ARDS. Most of the 
Table 3 Antithrombotic prophylaxis and treatment regimens in various settings of COVID-19 infection according to international societies

$\begin{aligned} & \text { Society/Document (PubMed ID } \\ & \text { number) }\end{aligned}$
Antithrombotic agent and dosage

number)

COVID-19 patients WITHOUT diagnosis of VTE

International Society of LMWH

Thrombosis and Haemostasis In standard VTE prophylactic dose, in

(ISTH) (PMID: 32338827)

STH - Subcommittee of

Perioperative and Critical

Thrombosis and Haemostasis of

the Scientific and

Standardization Committee

(PMID: 32459046) the absence of contraindications*

LMWH (preferred agent, once daily)

OR UFH (twice or thrice daily) OR

DOACs (least preferred, due to

interference $\mathrm{w} /$ immunosuppressant and antiviral drugs), in the absence of relevant contraindications*

All in standard VTE prophylactic doses**

Intermediate-dose LMWH in-hospital may be considered in severe patients

LMWH (preferred agent, once daily)

OR UFH (twice or thrice daily)

All in standard VTE prophylactic doses*

Intermediate-dose LMWH in-hospital can be considered in high-risk patients

Full-dose heparin treatment is

not recommended

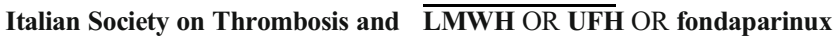
Haemostasis (SISET) (PMID: 32281926)

All in standard VTE prophylactic dose, in the absence of contraindications*

Intermediate-dose LMWH in-hospital (enoxaparin $4000 \mathrm{IU}$

subcutaneously, twice daily) could

be considered on an individual basis in patients with multiple risk factors for VTE

Full-dose heparin treatment is

not recommended

ISTH, North American

Thrombosis Forum (NATF),

European Society of Vascular

Medicine (ESVM), International

Union of Angiology (IUA),

European Society of Cardiology

(ESC) Working Group on the

Pulmonary Circulation and

Right Ventricular Function

(PMID: 32311448)

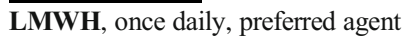
OR

UFH, twice daily

Both in standard VTE prophylactic dose, in the absence of contraindications*

Mechanical VTE prophylaxis in patients with contraindications in immobilized patients

Prophylactic anticoagulation is the only fully recommended modality

Intermediate-dose LMWH in-hospital could be an option in select patients (minority of the panel support this option)

Full-dose heparin treatment is not recommended

COVID-19 patients WITH confirmed diagnosis of VTE

\section{International Society of}

Thrombosis and Haemostasis

(ISTH) (PMID: 32338827)

ISTH - Subcommittee of

Perioperative and Critical

Thrombosis and Haemostasis of

the Scientific and

Standardization Committee

(PMID: 32459046) in-hospital LMWH should be

All COVID-19 patients who require During the whole duration of hospitalization (including non-critically ill patients)

All non-ICU hospitalized

COVID-19 patients

All ICU hospitalized COVID-19 patients hospital stay

During the whole duration of hospital stay

Extended duration thromboprophylaxis with LMWH or DOAC for 2-6 weeks (14 days at least, up to 30 days) post-discharge in selected patients with low risk for bleeding and key VTE risk factors could be used $* * * *$

During the whole duration of hospital stay

Extended duration thromboprophylaxis with LMWH or DOAC for 2-6 weeks (14 days at least, up to 30 days) post-discharge in selected patients with low risk for bleeding and key VTE risk factors could be used*****

All hospitalized COVID-19 patients During the whole duration of the hospital stay

Maintained at home for 7-14 days post-discharge in case of pre-existing or persisting VTE risk factors

Hospitalized patients with COVID-19 who have: respiratory failure or comorbidities such as active malignancy or heart failure, are bedridden or requiring intensive care
During the whole duration of hospital stay

Extended duration thromboprophylaxis with LMWH or DOAC for up to 45 days among patients with high VTE risk and low risk of bleeding $* * * *$

\section{LMWH}

(inpatient setting; a change from treatment-dose DOACs or VKAs to considered in critical care patients wtih relevant concomitant medications, based on renal function and thrombocyte count)
All hospitalized COVID-19 patients Duration of anticoagulation with established VTE treatment should be at least 3 months 
Table 3 (continued)

\begin{tabular}{|c|c|c|c|}
\hline $\begin{array}{l}\text { Society/Document (PubMed ID } \\
\text { number) }\end{array}$ & Antithrombotic agent and dosage & Population & Duration of treatment \\
\hline & $\begin{array}{l}\text { DOACs } \\
\text { (post-hospital discharge setting) } \\
\text { Standard VTE therapeutic doses in the } \\
\quad \text { absence of contraindications* } \\
\text { Prophylactic or intermediate-dose to } \\
\text { treatment-dose regimen might be } \\
\text { considered in patients without } \\
\text { verified VTE but with worsening } \\
\text { pulmonary status or ARDS }\end{array}$ & & \\
\hline $\begin{array}{l}\text { Italian Society on Thrombosis and } \\
\text { Haemostasis (SISET) (PMID: } \\
32281926)\end{array}$ & $\begin{array}{l}\text { LMWH } \\
\text { OR } \\
\text { UFH } \\
\text { OR } \\
\text { DOACs } \\
\text { Standard VTE therapeutic doses in the } \\
\quad \text { absence of contraindications* }\end{array}$ & $\begin{array}{l}\text { All hospitalized COVID-19 patients } \\
\text { with established VTE }\end{array}$ & $\begin{array}{l}\text { Duration of treatment in this } \\
\text { scenario should be according to } \\
\text { established classic guidelines for } \\
\text { therapeutic anticoagulation of } \\
\text { established VTE } \\
\text { In patients requiring therapeutic doses } \\
\text { of LMWH or DOACs, a careful } \\
\text { monitoring of renal function with } \\
\text { anti-factor Xa or plasma DOAC } \\
\text { levels assays should be instituted } \\
\text { VKAs and DOACS significantly } \\
\text { interfere with concomitant antiviral } \\
\text { treatment and individualized } \\
\text { risk/benefit approach should be } \\
\text { applied for every patient }\end{array}$ \\
\hline $\begin{array}{l}\text { ISTH, North American } \\
\text { Thrombosis Forum (NATF), } \\
\text { European Society of Vascular } \\
\text { Medicine (ESVM), International } \\
\text { Union of Angiology (IUA), } \\
\text { European Society of Cardiology } \\
\text { (ESC) Working Group on the } \\
\text { Pulmonary Circulation and } \\
\text { Right Ventricular Function } \\
\text { (PMID: 32311448) }\end{array}$ & $\begin{array}{l}\text { UFH, parenteral (preferred in critical } \\
\text { patients that might undergo } \\
\text { procedures) } \\
\text { OR } \\
\text { LMWH, subcutaneous (preferred in } \\
\text { patients unlikely to undergo } \\
\text { procedures) } \\
\text { DOACs OR LMWH } \\
\text { (preferred as post-discharge therapy } \\
\text { due to reduced need for contact with } \\
\text { healthcare workers required for INR } \\
\text { monitoring of VKAs) } \\
\text { All in standard VTE therapeutic doses, } \\
\text { in the absence of contraindications* } \\
\text { Mechanical VTE prophylaxis in } \\
\text { patients with contraindications in } \\
\text { immobilized patients }\end{array}$ & $\begin{array}{l}\text { Hospitalized patients with } \\
\text { COVID-19 with established VTE }\end{array}$ & $\begin{array}{l}\text { Duration of treatment in this } \\
\text { scenario should be according to } \\
\text { established classic guidelines for } \\
\text { therapeutic anticoagulation of } \\
\text { established VTE }\end{array}$ \\
\hline
\end{tabular}

$A R D S$, acute respiratory distress syndrome; $D O A C s$, direct oral anticoagulants; INR, international normalized ratio; LMWH, low molecular weight heparin; UFH-unfractionated heparin; VKA, vitamin K antagonist; VTE, venous thromboembolism

*Active bleeding, thrombocyte count $<25 \times 10^{9} / \mathrm{L}$, severe renal impairment (close monitoring required)

**Treatment should be modified individually according to patient's body weight, severity of thrombocytopenia $\left(25-50 \times 10^{9}\right.$ cells/L) or worsening renal function; intermittent pneumatic compression devices might be used in patients in whom anticoagulant therapy is contraindicated

$* * *$ Obese patients (body mass index $\geq 30$ ) should be considered for the $50 \%$ increase in the dose of thromboprophylaxis; multimodal prophylaxis with mechanical methods such as intermittent pneumonic compression devices should be considered

****High-risk factors defined as advanced age, stay in the ICU, cancer, a prior history of VTE, thrombophilia, severe immobility, elevated D-dimer levels ( $>2$ times of upper normal range), and an IMPROVE VTE score of 4 or more

inpatients with COVID-19 should receive at least prophylactic anticoagulation in the absence of contraindication, particularly those at ICU, due to high reported incidence of VTE in this context $[8,89]$. There are some observational studies suggesting that heparin improves the disease prognosis when the indication bias would suggest a worse prognosis (i.e., patients that received anticoagulation probably had an indication that could worsen the prognosis but the data suggests otherwise)
$[89,109]$. As there is no guidance for deciding the intensity of anticoagulation (prophylactic, intermediate, or therapeutic), the decision-making process should be made in individualcase basis, while studies are ongoing (NCT04377997, NCT04362085, NCT04367831). The suspicion of PE should be based in clinical grounds (unexplained chest pain, unexplained RV dysfunction, unilateral lower limb swelling) and not only in biomarkers such as D-dimers. It is known that D- 
dimers are frequently high in COVID-19 inpatients [62], they are a prognosis biomarker [114], but it is not clear if they reflect the existence of macrovascular thrombosis and/or the need to screen systematically VTE in these patients [108].

As for myocardial injury/infarction, there are also challenges because elevated troponin levels are often seen in COVID-19 patients, and the cause of troponin release may be multifactorial. First, both plaque rupture can occur during severe COVID-19 (type 1 myocardial infarction), and other causes of troponin release can be present, including imbalance between blood/oxygen supply and myocardial requirements, SARS-CoV-2 myocarditis, Tako-tsubo cardiomyopathy, or right heart failure (type 2 myocardial infarction). Patients with ST-elevation myocardial infarction (STEMI) or high-risk nonST-elevation acute coronary syndrome (NSTE-ACS) should go to the catheterization laboratory, preferably the one dedicated to COVID-19, and followed by an ICU isolation bed [115]. For patients with COVID-19 and STEMI in a non-primary PCI center, fibrinolysis can be considered depending on the current timings for patient transfer for a primary PCI center [115]. In the remaining patients with COVID-19 and NSTE-ACS, physicians can opt out for optimal medical treatment alone for clinical stabilization while further testing, or coronary angiography should be performed after the infection is resolved [115].

Stroke in COVID-19 patients was not as common as VTE [8]. The approach to stroke is the same as non-COVID-19 patients, pursuing the vessel recanalization when indicated and when resources are available [116]. Ideally, these patients should be at COVID-19 stroke units, but logistic difficulties have been seen during the COVID-19 season [117]. In patients with severe COVID-19 disease, the development of stroke signs and symptoms should also raise the suspicion of paradoxical embolism through atrial septum defect.

In summary, COVID-19 is an infectious disease that leads to a proinflammatory and prothrombotic state, resulting in both micro- and macrovascular thrombosis, and both arterial and venous thrombotic events. Therefore, the early recognition and vigilant monitoring of the thrombotic complication of COVID-19 may be life-saving.

Acknowledgments CIBERobn is an initiative of ISCIII, Spain.

Authors' Contributions All authors contributed to concept and design,
critical analysis of the literature and interpretation of data, critical writing
or revising the intellectual content, and final approval of the version to be
published.

Data Availability Not applicable.

\section{Compliance with Ethical Standards}

Conflict of Interest The authors declare that there are no conflicts of interest.
Code Availability Not applicable.

Open Access This article is licensed under a Creative Commons Attribution 4.0 International License, which permits use, sharing, adaptation, distribution and reproduction in any medium or format, as long as you give appropriate credit to the original author(s) and the source, provide a link to the Creative Commons licence, and indicate if changes were made. The images or other third party material in this article are included in the article's Creative Commons licence, unless indicated otherwise in a credit line to the material. If material is not included in the article's Creative Commons licence and your intended use is not permitted by statutory regulation or exceeds the permitted use, you will need to obtain permission directly from the copyright holder. To view a copy of this licence, visit http://creativecommons.org/licenses/by/4.0/.

\section{References}

1. Zhou P, Yang XL, Wang XG, Hu B, Zhang L, Zhang W, et al. A pneumonia outbreak associated with a new coronavirus of probable bat origin. Nature. 2020;579(7798):270-3. https://doi.org/10. 1038/s41586-020-2012-7.

2. World Health O. Coronavirus disease 2019 (COVID-19): situation report, 157. Geneva: World Health Organization; 2020.

3. Gómez-Carballa A, Bello X, Pardo-Seco J, Martinón-Torres F, Salas A (2020) The impact of super-spreaders in COVID-19: mapping genome variation worldwide. bioRxiv: 2020.2005.2019.097410. doi:https://doi.org/10.1101/2020.05.19. 097410

4. Mori J, Oudit GY, Lopaschuk GD. SARS-CoV-2 perturbs the Renin-Angiotensin System and energy metabolism. Am J Physiol Endocrinol Metab. 2020;319:E43-7. https://doi.org/10. 1152/ajpendo.00219.2020.

5. Gheblawi M, Wang K, Viveiros A, Nguyen Q, Zhong JC, Turner AJ, et al. Angiotensin-Converting Enzyme 2: SARS-CoV-2 Receptor and Regulator of the Renin-Angiotensin System: Celebrating the 20th Anniversary of the Discovery of ACE2. Circ Res. 2020;126(10):1456-74. https://doi.org/10.1161/ CIRCRESAHA.120.317015.

6. Ceriello A, Standl E, Catrinoiu D, Itzhak B, Lalic NM, Rahelic D, et al. Issues of Cardiovascular Risk Management in People With Diabetes in the COVID-19 Era. Diabetes Care. 2020;43:1427-32. https://doi.org/10.2337/dc20-0941.

7. Adao R, Guzik TJ. Inside the heart of COVID-19. Cardiovasc Res. 2020;116(6):e59-61. https://doi.org/10.1093/cvr/cvaa086.

8. Al-Ani F, Chehade S, Lazo-Langner A. Thrombosis risk associated with COVID-19 infection. A scoping review. Thromb Res. 2020;192:152-60. https://doi.org/10.1016/j.thromres.2020.05. 039.

9. Marchandot B, Sattler L, Jesel L, Matsushita K, Schini-Kerth V, Grunebaum L, et al. COVID-19 Related Coagulopathy: A Distinct Entity? J Clin Med. 2020;9(6). https://doi.org/10.3390/ jcm9061651.

10. Parker WAE, Storey RF (2018) 'Thrombotic Response' in ESC Textbook of Cardiovascular Medicine 3rd edition.

11. Bagot CN, Arya R. Virchow and his triad: a question of attribution. Br J Haematol. 2008;143(2):180-90. https://doi.org/10.1111/ j.1365-2141.2008.07323.x.

12. Parker WAE, Orme RC, Hanson J, Stokes HM, Bridge CM, Shaw $\mathrm{PA}$, et al. Very-low-dose twice-daily aspirin maintains platelet inhibition and improves haemostasis during dual-antiplatelet therapy for acute coronary syndrome. Platelets. 2019;30(2):148-57. https://doi.org/10.1080/09537104.2019.1572880. 
13. Parker WA, Storey RF. Long-term antiplatelet therapy following myocardial infarction: implications of PEGASUS-TIMI 54. Heart. 2016;102(10):783-9. https://doi.org/10.1136/heartjnl-2015307858 .

14. Storey RF, Sanderson HM, White AE, May JA, Cameron KE, Heptinstall $\mathrm{S}$. The central role of the $\mathrm{P}(2 \mathrm{~T})$ receptor in amplification of human platelet activation, aggregation, secretion and procoagulant activity. Br J Haematol. 2000;110(4):925-34.

15. Storey RF, Judge HM, Wilcox RG, Heptinstall S. Inhibition of ADP-induced P-selectin expression and platelet-leukocyte conjugate formation by clopidogrel and the P2Y12 receptor antagonist AR-C69931MX but not aspirin. Thromb Haemost. 2002;88:48894. https://doi.org/10.1055/s-0037-1613242.

16. Sanderson HM, Heptinstall S, Vickers J, Losche W. Studies on the effects of agonists and antagonists on platelet shape change and platelet aggregation in whole blood. Blood Coagul Fibrinolysis. 1996; 7:245-8.

17. Cho MJ, Liu J, Pestina TI, Steward SA, Jackson CW, Gartner TK. $\mathrm{a}_{\mathrm{IIb}} \mathrm{b}_{3}$-mediated outside-in signaling induced by the agonist peptide LSARLAF utilizes ADP and thromboxane A2 receptors to cause a-granule secretion by platelets. J Thromb Haemost : JTH. 2003;1(2):363-73.

18. Badimon L, Suades R, Vilella-Figuerola A, Crespo J, Vilahur G, Escate R, et al. Liquid Biopsies: Microvesicles in Cardiovascular Disease. Antioxid Redox Signal. 2019;33:645-62. https://doi.org/ 10.1089/ars.2019.7922.

19. Gasecka A, Böing AN, Filipiak KJ, Nieuwland R. Platelet extracellular vesicles as biomarkers for arterial thrombosis. Platelets. 2017;28(3):228-34. https://doi.org/10.1080/09537104.2016. 1254174 .

20. Sinauridze EI, Kireev Da Fau-Popenko NY, Popenko Ny FauPichugin AV, Pichugin Av Fau-Panteleev MA, Panteleev Ma Fau-Krymskaya OV, Krymskaya Ov Fau-Ataullakhanov FI, Ataullakhanov FI Platelet microparticle membranes have 50- to 100 -fold higher specific procoagulant activity than activated platelets. (0340-6245 (Print))

21. Ajjan R, Grant PJ. Coagulation and atherothrombotic disease. Atherosclerosis. 2006;186(2):240-59. https://doi.org/10.1016/j. atherosclerosis.2005.10.042.

22. Bevers EM, Comfurius P, VanRijn JLML, Hemker HC, Zwall RFA. Generation of prothrombin-converting activity and the exposure of phosphatidylserine at the outer surface of platelets. Eur J Biochem. 1982;122:429-36.

23. Jackson SP. Arterial thrombosis-insidious, unpredictable and deadly. Nat Med. 2011;17(11):1423-36. https://doi.org/10.1038/ nm. 2515 .

24. Koupenova M, Kehrel BE, Corkrey HA, Freedman JE. Thrombosis and platelets: an update. Eur Heart J. 2016;38(11): 785-91. https://doi.org/10.1093/eurheartj/ehw550.

25. Kawai T, Akira S. The role of pattern-recognition receptors in innate immunity: update on Toll-like receptors. Nat Immunol. 2010;11(5):373-84. https://doi.org/10.1038/ni.1863.

26. Chaplin DD. Overview of the immune response. J Allergy Clin Immunol. 2010;125(2 Suppl 2):S3-23. https://doi.org/10.1016/j. jaci.2009.12.980.

27. Chen G, Wu D, Guo W, Cao Y, Huang D, Wang H, et al. Clinical and immunological features of severe and moderate coronavirus disease 2019. J Clin Invest. 2020;130(5):2620-9. https://doi.org/ $10.1172 /$ jci137244.

28. Herold T, Jurinovic V, Arnreich C, Lipworth BJ, Hellmuth JC, von Bergwelt-Baildon $\mathrm{M}$, et al. Elevated levels of interleukin-6 and CRP predict the need for mechanical ventilation in COVID19. J Allergy Clin Immunol. 2020;146:128-136.e4. https://doi. org/10.1016/j.jaci.2020.05.008.

29. Thomas MR, Outteridge SN, Ajjan RA, Phoenix F, Sangha GK, Faulkner RE, et al. Platelet P2Y12 Inhibitors Reduce Systemic
Inflammation and Its Prothrombotic Effects in an Experimental Human Model. Arterioscler Thromb Vasc Biol. 2015;35(12): 2562-70. https://doi.org/10.1161/atvbaha.115.306528.

30. Kiers D, van der Heijden WA, van Ede L, Gerretsen J, de Mast Q, van der Ven AJ, et al. A randomised trial on the effect of antiplatelet therapy on the systemic inflammatory response in human endotoxaemia. Thromb Haemost. 2017;117(9):1798-807. https:// doi.org/10.1160/th16-10-0799.

31. Akinosoglou K, Theodoraki S, Xanthopoulou I, Perperis A, Gkavogianni T, Pistiki A, et al. Platelet reactivity in sepsis syndrome: results from the PRESS study. Eur J Clin Microbiol Infect Dis. 2017;36(12):2503-12. https://doi.org/10.1007/s10096-0173093-6.

32. Kaser A, Brandacher G, Steurer W, Kaser S, Offner FA, Zoller H, et al. Interleukin-6 stimulates thrombopoiesis through thrombopoietin: role in inflammatory thrombocytosis. Blood. 2001;98(9):2720-5. https://doi.org/10.1182/blood.v98.9.2720.

33. Gasparyan AY, Ayvazyan L, Mikhailidis DP, Kitas GD. Mean platelet volume: a link between thrombosis and inflammation? Curr Pharm Des. 2011;17(1):47-58. https://doi.org/10.2174/ 138161211795049804.

34. Enz Hubert RM, Rodrigues MV, Andreguetto BD, Santos TM, de Fátima Pereira Gilberti M, de Castro V, et al. Association of the immature platelet fraction with sepsis diagnosis and severity. Sci Rep. 2015;5:8019. https://doi.org/10.1038/srep08019.

35. Ridger VC, Boulanger CM, Angelillo-Scherrer A, Badimon L, Blanc-Brude O, Bochaton-Piallat ML, et al. Microvesicles in vascular homeostasis and diseases. Position Paper of the European Society of Cardiology (ESC) Working Group on Atherosclerosis and Vascular Biology. Thromb Haemost. 2017;117(7):1296-316. https://doi.org/10.1160/TH16-12-0943.

36. Bevan J, Heptinstall S. Serotonin-induced platelet aggregation in whole blood and the effects of ketanserin and mepyramine. Thromb Res. 1985;38:189-94.

37. Keularts IMLW, van Gorp RMA, Feijge MAH, Vuist WMJ, Heemskerk JWM. $\mathrm{a}_{2 \mathrm{~A}}$-adrenergic receptor stimulation potentiates calcium release in platelets by modulating cAMP levels. J Biol Chem. 2000;275:1763-72.

38. Petros S, Kliem P, Siegemund T, Siegemund R. Thrombin generation in severe sepsis. Thromb Res. 2012;129(6):797-800. https:// doi.org/10.1016/j.thromres.2011.08.004.

39. Chen D, Dorling A. Critical roles for thrombin in acute and chronic inflammation. J Thromb Haemost : JTH. 2009; 7(Suppl 1):1226. https://doi.org/10.1111/j.1538-7836.2009.03413.x.

40. Levi M. Disseminated intravascular coagulation. Crit Care Med. 2007;35(9):2191-5. https://doi.org/10.1097/01.ccm.0000281468. $94108.4 \mathrm{~b}$.

41. Ince C, Mayeux PR, Nguyen T, Gomez H, Kellum JA, OspinaTascón GA, et al. THE ENDOTHELIUM IN SEPSIS. Shock. 2016;45(3):259-70. https://doi.org/10.1097/shk. 0000000000000473 .

42. Libby P, Buring JE, Badimon L, Hansson GK, Deanfield J, Bittencourt MS, et al. Atherosclerosis. Nat Rev Disease Primers. 2019;5(1):56. https://doi.org/10.1038/s41572-019-0106-z.

43. Guo T, Fan Y, Chen M, Wu X, Zhang L, He T, et al. Cardiovascular Implications of Fatal Outcomes of Patients With Coronavirus Disease 2019 (COVID-19). JAMA Cardiol. 2020;5: 811-8. https://doi.org/10.1001/jamacardio.2020.1017.

44. Zhou F, Yu T, Du R, Fan G, Liu Y, Liu Z, et al. Clinical course and risk factors for mortality of adult inpatients with COVID-19 in Wuhan, China: a retrospective cohort study. Lancet. 2020;395(10229):1054-62. https://doi.org/10.1016/S01406736(20)30566-3.

45. Lodigiani C, Iapichino G, Carenzo L, Cecconi M, Ferrazzi P, Sebastian T, et al. Venous and arterial thromboembolic complications in COVID-19 patients admitted to an academic hospital in 
Milan, Italy. Thromb Res. 2020;191:9-14. https://doi.org/10. 1016/j.thromres.2020.04.024.

46. Poissy J, Goutay J, Caplan M, Parmentier E, Duburcq T, Lassalle F, et al. Pulmonary Embolism in COVID-19 Patients: Awareness of an Increased Prevalence. Circulation. 2020;142:184-6. https:// doi.org/10.1161/CIRCULATIONAHA.120.047430.

47. Klok FA, Kruip M, van der Meer NJM, Arbous MS, Gommers D, Kant KM, et al. Incidence of thrombotic complications in critically ill ICU patients with COVID-19. Thromb Res. 2020;191:145-7. https://doi.org/10.1016/j.thromres.2020.04.013.

48. Klok FA, Kruip M, van der Meer NJM, Arbous MS, Gommers D, Kant KM, et al. Confirmation of the high cumulative incidence of thrombotic complications in critically ill ICU patients with COVID-19: An updated analysis. Thromb Res. 2020;191:148 50. https://doi.org/10.1016/j.thromres.2020.04.041.

49. Middeldorp S, Coppens M, van Haaps TF, Foppen M, Vlaar AP, Müller MCA, et al. Incidence of venous thromboembolism in hospitalized patients with COVID-19. J Thromb Haemost : JTH. 2020;18:1995-2002. https://doi.org/10.1111/jth.14888.

50. Helms J, Tacquard C, Severac F, Leonard-Lorant I, Ohana M, Delabranche $\mathrm{X}$, et al. High risk of thrombosis in patients with severe SARS-CoV-2 infection: a multicenter prospective cohort study. Intensive Care Med. 2020;46:1089-98. https://doi.org/10. 1007/s00134-020-06062-x.

51. Llitjos JF, Leclerc M, Chochois C, Monsallier JM, Ramakers M, Auvray M, et al. High incidence of venous thromboembolic events in anticoagulated severe COVID-19 patients. J Thromb Haemost : JTH. 2020;18:1743-6. https://doi.org/10.1111/jth. 14869.

52. Cui S, Chen S, Li X, Liu S, Wang F. Prevalence of venous thromboembolism in patients with severe novel coronavirus pneumonia. J Thromb Haemost. 2020;18(6):1421-4. https://doi.org/10.1111/ jth. 14830 .

53. Thomas W, Varley J, Johnston A, Symington E, Robinson M, Sheares K, et al. Thrombotic complications of patients admitted to intensive care with COVID-19 at a teaching hospital in the United Kingdom. Thromb Res. 2020;191:76-7. https://doi.org/ 10.1016/j.thromres.2020.04.028.

54. Leonard-Lorant I, Delabranche X, Severac F, Helms J, Pauzet C, Collange O, Schneider F, Labani A, Bilbault P, Moliere S, Leyendecker P, Roy C, Ohana M (2020) Acute Pulmonary Embolism in COVID-19 Patients on CT Angiography and Relationship to D-Dimer Levels. Radiology:201561. doi:https:// doi.org/10.1148/radiol.2020201561

55. Grillet F, Behr J, Calame P, Aubry S, Delabrousse E (2020) Acute Pulmonary Embolism Associated with COVID-19 Pneumonia Detected by Pulmonary CT Angiography. Radiology:201544. doi:https://doi.org/10.1148/radiol.2020201544

56. Cattaneo M, Bertinato EM, Birocchi S, Brizio C, Malavolta D, Manzoni M, et al. Pulmonary Embolism or Pulmonary Thrombosis in COVID-19? Is the Recommendation to Use High-Dose Heparin for Thromboprophylaxis Justified? Thromb Haemost. 2020;120:1230-2. https://doi.org/10.1055/s-00401712097.

57. Wichmann D, Sperhake JP, Lutgehetmann M, Steurer S, Edler C, Heinemann A, et al. Autopsy Findings and Venous Thromboembolism in Patients With COVID-19. Ann Intern Med. 2020;173:268-77. https://doi.org/10.7326/M20-2003.

58. Bompard F, Monnier H, Saab I, Tordjman M, Abdoul H, Fournier L, et al. Pulmonary embolism in patients with Covid-19 pneumonia. Eur Respir J. 2020;56:2001365. https://doi.org/10.1183/ 13993003.01365-2020.

59. Zhang L, Feng X, Zhang D, Jiang C, Mei H, Wang J, et al. Deep Vein Thrombosis in Hospitalized Patients with Coronavirus Disease 2019 (COVID-19) in Wuhan, China: Prevalence, Risk
Factors, and Outcome. Circulation. 2020;142:114-28. https:// doi.org/10.1161/CIRCULATIONAHA.120.046702.

60. Morassi M, Bagatto D, Cobelli M, D’Agostini S, Gigli GL, Bna C, et al. Stroke in patients with SARS-CoV-2 infection: case series. J Neurol. 2020;267:2185-92. https://doi.org/10.1007/s00415-02009885-2.

61. Li Y, Wang M, Zhou Y, Chang J, Xian Y, Mao L, Hong C, Chen S, Wang Y, Wang H (2020) Acute cerebrovascular disease following COVID-19: a single center, retrospective, observational study.

62. Huang C, Wang Y, Li X, Ren L, Zhao J, Hu Y, et al. Clinical features of patients infected with 2019 novel coronavirus in Wuhan, China. Lancet. 2020;395(10223):497-506. https://doi. org/10.1016/S0140-6736(20)30183-5.

63. Wang D, Hu B, Hu C, Zhu F, Liu X, Zhang J, et al. Clinical Characteristics of 138 Hospitalized Patients With 2019 Novel Coronavirus-Infected Pneumonia in Wuhan, China. Jama. 2020;323:1061-9. https://doi.org/10.1001/jama.2020.1585.

64. Yang J, Zheng Y, Gou X, Pu K, Chen Z, Guo Q, et al. Prevalence of comorbidities and its effects in patients infected with SARSCoV-2: a systematic review and meta-analysis. Int J Infect Dis. 2020;94:91-5. https://doi.org/10.1016/j.ijid.2020.03.017.

65. Shi S, Qin M, Shen B, Cai Y, Liu T, Yang F, et al. Association of Cardiac Injury With Mortality in Hospitalized Patients With COVID-19 in Wuhan, China. JAMA Cardiol. 2020;5:802-10. https://doi.org/10.1001/jamacardio.2020.0950.

66. Tersalvi G, Vicenzi M, Calabretta D, Biasco L, Pedrazzini G, Winterton D. Elevated Troponin in Patients With Coronavirus Disease 2019: Possible Mechanisms. J Card Fail. 2020;26:470 5. https://doi.org/10.1016/j.cardfail.2020.04.009.

67. Sala S, Peretto G, Gramegna M, Palmisano A, Villatore A, Vignale D, et al. Acute myocarditis presenting as a reverse Tako-Tsubo syndrome in a patient with SARS-CoV-2 respiratory infection. Eur Heart J. 2020;41(19):1861-2. https://doi.org/10. 1093/eurheartj/ehaa286.

68. Pfeiler S, Massberg S, Engelmann B. Biological basis and pathological relevance of microvascular thrombosis. Thromb Res. 2014;133(Suppl 1):S35-7. https://doi.org/10.1016/j.thromres. 2014.03.016

69. Gando S. Microvascular thrombosis and multiple organ dysfunction syndrome. Crit Care Med. 2010;38(2 Suppl):S35-42. https:// doi.org/10.1097/CCM.0b013e3181c9e31d.

70. Levi M. Disseminated intravascular coagulation: a diseasespecific approach. Semin Thromb Hemost. 2010;36(4):363-5. https://doi.org/10.1055/s-0030-1254045.

71. Becker RC. COVID-19 update: Covid-19-associated coagulopathy. J Thromb Thrombolysis. 2020;50:54-67. https://doi.org/10. 1007/s11239-020-02134-3.

72. Tang N, Li D, Wang X, Sun Z. Abnormal coagulation parameters are associated with poor prognosis in patients with novel coronavirus pneumonia. J Thromb Haemost : JTH. 2020;18(4):844-7. https://doi.org/10.1111/jth.14768.

73. Levi M, Thachil J, Iba T, Levy JH. Coagulation abnormalities and thrombosis in patients with COVID-19. The Lancet Haematology. 2020;7(6):e438-40. https://doi.org/10.1016/s2352-3026(20) 30145-9.

74. Fox SE, Akmatbekov A, Harbert JL, Li G, Quincy Brown J, Vander Heide RS. Pulmonary and cardiac pathology in African American patients with COVID-19: an autopsy series from New Orleans. Lancet Respir Med. 2020;8:681-6. https://doi.org/10. 1016/S2213-2600(20)30243-5.

75. Magro C, Mulvey JJ, Berlin D, Nuovo G, Salvatore S, Harp J, et al. Complement associated microvascular injury and thrombosis in the pathogenesis of severe COVID-19 infection: a report of five cases. Transl Res : the journal of laboratory and clinical medicine. 2020;220:1-13. https://doi.org/10.1016/j.trsl.2020.04.007. 
76. Ciceri F, Beretta L, Scandroglio AM, Colombo S, Landoni G, Ruggeri A, Peccatori J, D’Angelo A, De Cobelli F, RovereQuerini P, Tresoldi M, Dagna L, Zangrillo A (2020) Microvascular COVID-19 lung vessels obstructive thromboinflammatory syndrome (MicroCLOTS): an atypical acute respiratory distress syndrome working hypothesis. Crit Care Resusc

77. McGonagle D, O’Donnell JS, Sharif K, Emery P, Bridgewood C. Immune mechanisms of pulmonary intravascular coagulopathy in COVID-19 pneumonia. The Lancet Rheumatology. 2020. https:// doi.org/10.1016/S2665-9913(20)30121-1.

78. Hamming I, Timens W, Bulthuis ML, Lely AT, Navis G, van Goor H. Tissue distribution of ACE2 protein, the functional receptor for SARS coronavirus. A first step in understanding SARS pathogenesis. J Pathol. 2004;203(2):631-7. https://doi.org/10. 1002/path. 1570 .

79. Yang HZ, Oppenheim JJ. Alarmins and immunity. Immunol Rev. 2017;280(1):41-56. https://doi.org/10.1111/imr.12577.

80. Muller I, Klocke A, Alex M, Kotzsch M, Luther T, Morgenstern $\mathrm{E}$, et al. Intravascular tissue factor initiates coagulation via circulating microvesicles and platelets. FASEB J : official publication of the Federation of American Societies for Experimental Biology. 2003;17(3):476-8. https://doi.org/10.1096/fj.02-0574fje.

81. Zuo Y, Yalavarthi S, Shi H, Gockman K, Zuo M, Madison JA, Blair C, Weber A, Barnes BJ, Egeblad M, Woods RJ, Kanthi Y, Knight JS (2020) Neutrophil extracellular traps in COVID-19. JCI insight 5 (11). doi:https://doi.org/10.1172/jci.insight.138999

82. Kannemeier C, Shibamiya A, Nakazawa F, Trusheim H, Ruppert C, Markart P, et al. Extracellular RNA constitutes a natural procoagulant cofactor in blood coagulation. Proc Natl Acad Sci U S A. 2007;104(15):6388-93. https://doi.org/10.1073/pnas. 0608647104.

83. Li B, Liu Y, Hu T, Zhang Y, Zhang C, Li T, et al. Neutrophil extracellular traps enhance procoagulant activity in patients with oral squamous cell carcinoma. J Cancer Res Clin Oncol. 2019;145(7):1695-707. https://doi.org/10.1007/s00432-01902922-2.

84. Barnes BJ, Adrover JM, Baxter-Stoltzfus A, Borczuk A, CoolsLartigue J, Crawford JM, Dassler-Plenker J, Guerci P, Huynh C, Knight JS, Loda M, Looney MR, McAllister F, Rayes R, Renaud S, Rousseau S, Salvatore S, Schwartz RE, Spicer JD, Yost CC, Weber A, Zuo Y, Egeblad M (2020) Targeting potential drivers of COVID-19: Neutrophil extracellular traps. J Exp Med 217 (6). doi:https://doi.org/10.1084/jem.20200652

85. Boukour S, Masse JM, Benit L, Dubart-Kupperschmitt A, Cramer EM. Lentivirus degradation and DC-SIGN expression by human platelets and megakaryocytes. J Thromb Haemost : JTH. 2006;4(2):426-35. https://doi.org/10.1111/j.1538-7836.2006. 01749.x.

86. Middleton EA, Weyrich AS, Zimmerman GA. Platelets in Pulmonary Immune Responses and Inflammatory Lung Diseases. Physiol Rev. 2016;96(4):1211-59. https://doi.org/10. 1152/physrev.00038.2015.

87. Rondina MT, Brewster B, Grissom CK, Zimmerman GA, Kastendieck DH, Harris ES, et al. In vivo platelet activation in critically ill patients with primary 2009 influenza A(H1N1). Chest. 2012;141(6):1490-5. https://doi.org/10.1378/chest.112860.

88. Yang M, Ng MH, Li CK. Thrombocytopenia in patients with severe acute respiratory syndrome (review). Hematology. 2005;10(2):101-5. https://doi.org/10.1080/10245330400026170.

89. Kollias A, Kyriakoulis KG, Dimakakos E, Poulakou G, Stergiou GS, Syrigos K. Thromboembolic risk and anticoagulant therapy in COVID-19 patients: emerging evidence and call for action. Br J Haematol. 2020;189(5):846-7. https://doi.org/10.1111/bjh.16727.
90. Galeano-Valle F, Oblitas CM, Ferreiro-Mazón MM, AlonsoMuñoz J, Del Toro-Cervera J, di Natale M, et al. Antiphospholipid antibodies are not elevated in patients with severe COVID-19 pneumonia and venous thromboembolism. Thromb Res. 2020;192:113-5. https://doi.org/10.1016/j. thromres.2020.05.017.

91. Hippensteel JA, Burnham EL, Jolley SE. Prevalence of Venous Thromboembolism in Critically Ill Patients with COVID-19. Br J Haematol. 2020;190:e134-7. https://doi.org/10.1111/bjh.16908.

92. Parry AH, Wani AH. Pulmonary embolism in coronavirus disease-19 (COVID-19) and use of compression ultrasonography in its optimal management. Thromb Res. 2020;192:36. https://doi. org/10.1016/j.thromres.2020.05.022.

93. Marone EM, Rinaldi LF. Upsurge of deep venous thrombosis in patients affected by COVID-19: Preliminary data and possible explanations. J Vasc Surg Venous Lymphat Disord. 2020;S2213-2333X(2220):30214-6. https://doi.org/10.1016/j. jvsv.2020.04.004.

94. Zhang L, Wang B, Zhou J, Kirkpatrick J, Xie M, Johri AM. Bedside Focused Cardiac Ultrasound in COVID-19 Infection From the Wuhan Epicenter: The Role of Cardiac Point of Care Ultrasound (POCUS). Limited Transthoracic Echocardiography and Critical Care Echocardiography. J Am Soc Echocardiogr. 2020;33:676-82. https://doi.org/10.1016/j.echo.2020.04.004.

95. Argulian E, Sud K, Vogel B, Bohra C, Garg VP, Talebi S, Lerakis S, Narula J (2020) Right Ventricular Dilation in Hospitalized Patients with COVID-19 Infection. JACC: Cardiovasc Imaging 3443. doi:https://doi.org/10.1016/j.jcmg.2020.05.010

96. Zhang L, Yan X, Fan Q, Liu H, Liu X, Liu Z, et al. D-dimer levels on admission to predict in-hospital mortality in patients with Covid-19. J Thromb Haemost : JTH. 2020;18:1324-9. https:// doi.org/10.1111/jth.14859.

97. Wright FL, Vogler TO, Moore EE, Moore HB, Wohlauer MV, Urban S, et al. Fibrinolysis Shutdown Correlates to Thromboembolic Events in Severe COVID-19 Infection. J Am Coll Surg. 2020;231:193-203.e1. https://doi.org/10.1016/j. jamcollsurg.2020.05.007.

98. Tian W, Jiang W, Yao J, Nicholson CJ, Li RH, Sigurslid HH, et al. Predictors of mortality in hospitalized COVID-19 patients: A systematic review and meta-analysis. J Med Virol. 2020. https://oi. org/10.1002/jmv.26050.

99. Bilaloglu S, Aphinyanaphongs Y, Jones S, Iturrate E, Hochman J, Berger JS. Thrombosis in Hospitalized Patients With COVID-19 in a New York City Health System. JAMA. 2020;324:799-801. https://doi.org/10.1001/jama.2020.13372.

100. Connors JM, Levy JH. Thromboinflammation and the hypercoagulability of COVID-19. J Thromb Haemost n/a (n/a). 2020;18: 1559-61. https://doi.org/10.1111/jth.14849.

101. Terpos E, Ntanasis-Stathopoulos I, Elalamy I, Kastritis E, Sergentanis TN, Politou M, et al. Hematological findings and complications of COVID-19. Am J Hematol. 2020;95:834-47. https://doi.org/10.1002/ajh.25829.

102. Ranucci M, Ballotta A, Di Dedda U, Bayshnikova E, Dei Poli M, Resta M, et al. The procoagulant pattern of patients with COVID19 acute respiratory distress syndrome. J Thromb Haemost : JTH. 2020;18:1747-51. https://doi.org/10.1111/jth.14854.

103. Panigada M, Bottino N, Tagliabue P, Grasselli G, Novembrino C, Chantarangkul V, et al. Hypercoagulability of COVID-19 patients in Intensive Care Unit. A Report of Thromboelastography Findings and other Parameters of Hemostasis. J Thromb Haemost. 2020;18:1738-42. https://doi.org/10.1111/jth.14850.

104. Maier CL, Truong AD, Auld SC, Polly DM, Tanksley C-L, Duncan A. COVID-19-associated hyperviscosity: a link between inflammation and thrombophilia? Lancet. 2020;395:1758-9. https://doi.org/10.1016/S0140-6736(20)31209-5. 
105. Marietta M, Ageno W, Artoni A, De Candia E, Gresele P, Marchetti M, et al. COVID-19 and haemostasis: a position paper from Italian Society on Thrombosis and Haemostasis (SISET). Blood Transf $=$ Trasfusione del sangue. 2020;18(3):167-9. https://doi.org/10.2450/2020.0083-20.

106. Thachil J, Tang N, Gando S, Falanga A, Cattaneo M, Levi M, et al. ISTH interim guidance on recognition and management of coagulopathy in COVID-19. J Thromb Haemost : JTH. 2020;18(5): 1023-6. https://doi.org/10.1111/jth.14810.

107. Spyropoulos AC, Levy JH, Ageno W, Connors JM, Hunt BJ, Iba $\mathrm{T}$, et al. Scientific and Standardization Committee Communication: Clinical Guidance on the Diagnosis, Prevention and Treatment of Venous Thromboembolism in Hospitalized Patients with COVID-19. J Thromb Haemost n/a (n/a). 2020;18: 1859-65. https://doi.org/10.1111/jth.14929.

108. Bikdeli B, Madhavan MV, Jimenez D, Chuich T, Dreyfus I, Driggin E, et al. COVID-19 and Thrombotic or Thromboembolic Disease: Implications for Prevention, Antithrombotic Therapy, and Follow-up. J Am Coll Cardiol. 2020;75:2950-73. https://doi.org/10.1016/j.jacc.2020.04.031.

109. Tang N, Bai H, Chen X, Gong J, Li D, Sun Z. Anticoagulant treatment is associated with decreased mortality in severe coronavirus disease 2019 patients with coagulopathy. J Thromb Haemost : JTH. 2020;18(5):1094-9. https://doi.org/10.1111/jth.14817.

110. Paranjpe I, Fuster V, Lala A, Russak A, Glicksberg BS, Levin MA, Charney AW, Narula J, Fayad ZA, Bagiella E, Zhao S, Nadkarni GN (2020) Association of Treatment Dose Anticoagulation with In-Hospital Survival Among Hospitalized Patients with COVID-19. J Am Coll Cardiol 27327. doi:https:// doi.org/10.1016/j.jacc.2020.05.001
111. Mousavi S, Moradi M, Khorshidahmad T, Motamedi M. AntiInflammatory Effects of Heparin and Its Derivatives: A Systematic Review. Adv Pharmacol Sci. 2015;2015:507151. https://doi.org/10.1155/2015/507151.

112. Young E. The anti-inflammatory effects of heparin and related compounds. Thromb Res. 2008;122(6):743-52. https://doi.org/ 10.1016/j.thromres.2006.10.026.

113. Desborough MJR, Doyle AJ, Griffiths A, Retter A, Breen KA, Hunt BJ. Image-proven thromboembolism in patients with severe COVID-19 in a tertiary critical care unit in the United Kingdom. Thromb Res. 2020;193:1-4. https://doi.org/10.1016/j.thromres. 2020.05.049.

114. Lippi G, Favaloro EJ. D-dimer is Associated with Severity of Coronavirus Disease 2019: A Pooled Analysis. Thromb Haemost. 2020;120(5):876-8. https://doi.org/10.1055/s-00401709650 .

115. Mahmud E, Dauerman HL, Welt FG, Messenger JC, Rao SV, Grines C, et al. Management of acute myocardial infarction during the COVID-19 pandemic. J Am Coll Cardiol. 2020;76:1375-84.

116. Ospel JM, Goyal M. Endovascular stroke treatment during the COVID-19 pandemic. Nat Rev Neurol. 2020;16:1-2. https://doi. org/10.1038/s41582-020-0371-1.

117. Bersano A, Kraemer M, Touzé E, Weber R, Alamowitch S, Sibon I, et al. Stroke care during the Covid-19 pandemic: Experience from three large European countries. Eur J Neurol : the official journal of the European Federation of Neurological Societies. 2020;27:1794-800. https://doi.org/10.1111/ene.14375.

Publisher's Note Springer Nature remains neutral with regard to jurisdictional claims in published maps and institutional affiliations.

\section{Affiliations}

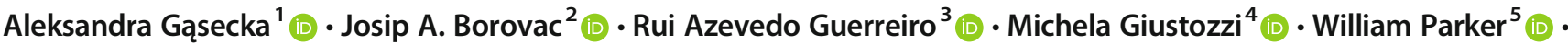 Daniel Caldeira $^{6,7}$ (D) $\cdot$ Gemma Chiva-Blanch ${ }^{8,9}$ (D)}

$1 \quad 1$ st Chair and Department of Cardiology, Medical University of Warsaw, Warsaw, Poland

2 Department of Pathophysiology, University of Split School of Medicine, Split, Croatia

3 Cardiology Department, Hospital do Espírito Santo, Évora, Portugal

4 Internal Vascular and Emergency Medicine and Stroke Unit, University of Perugia, Perugia, Italy

5 Cardiovascular Research Unit, University of Sheffield, Sheffield, UK
6 Centro Cardiovascular da Universidade de Lisboa (CCUL), Faculdade de Medicina, Univerisdade de Lisboa, Lisbon, Portugal

7 Cardiology Department, Hospital Universitário de Santa Maria (CHULN), Avenida Professor Egas Moniz, 1649028 Lisbon, Portugal

8 Department of Endocrinology and Nutrition, August Pi i Sunyer Biomedical Research Institute (IDIBAPS), Hospital Clínic of Barcelona, Barcelona, Spain

9 Spanish Biomedical Research Network in Physiopathology of Obesity and Nutrition (CIBEROBN), ISCIII, Madrid, Spain 